\title{
RENDEZVÉNYEKKEL A VIDÉK EGÉSZSÉGÉÉRT ÉS ÉLHETÓSÉGÉÉRT
}

\section{EVENTS FOR THE HEALTH AND LIVABILITY OF THE COUNTRYSIDE}

\author{
Major Zsigmond ${ }^{1}$ \\ ${ }^{1}$ Debreceni Egyetem Gazdaságtudományi Kar, Magyarország
}

\author{
Kulcsszavak: \\ vidék, életminőség, életszínvonal, gazdaság, fejlesztési lehetőségek \\ Keywords: \\ countryside, quality of life, standard of living, economy, development opportunities
}

\begin{abstract}
Összefoglalás
Az elmúlt évek során folyamatosan növekszik az egészséges életmóddal, az egészséggel, az ezekhez kapcsolódó magatartási formákkal kapcsolatos vizsgálatok száma, amelyek a mindennapi életre gyakorolt hatásukat is elemzik. Jelen cikk arra az igen tág kérdésre keresi a választ, hogy miként lehet növelni a jólétet és az életszínvonalat a vidéki területeken. A téma vidéki aspektusba történő helyezése kiemelt társadalmi jelentöséggel bír, mivel nemcsak az EU-ban, hazánkban is meghatározó részarányt képvisel a vidéki terület.
\end{abstract}

\section{Abstract}

In recent years, the number of investigations related to healthy lifestyles, health and behavioral aspects of the listed topics are continuously growing. These research activities also analyze the links and the impacts of these topics on the everyday life. This article seeks to answer the very broad question of how to increase prosperity and living standards in rural areas. Placing the topic in the rural aspect is of special social significance, as the rural area represents a significant share not only in the EU, but also in Hungary.

\section{Bevezetés}

Napjaink egyik kiemelt aktualitással bíró témája a vidék jövőképe, a vidéki népesség helyzete. Noha a globális urbanizációs tendenciák eredményeként a népesség egyre nagyobb aránya él városokban [9], a vidéki térségekben lakó emberek szerepe a gazdaság múködésében továbbra is megkerülhetetlen [50]. Elengedhetetlenül fontos volna, hogy a rurális területek kisebb-nagyobb településein élő lakosok is annyi lehetőséget találjanak életük élhetőségének fokozására, egészségük védelmére, mint a városi közegben élő társaik.

Napjainkban egyre több település dönt úgy, hogy évről évre, jellemzően ismétlődő módon és azonos időszakban, valamilyen rendezvényt kínál a lakosoknak és az odalátogatóknak. A vidéki térségek kisebb települései is így tesznek, amelyek esetében a helyi hagyományok őrzése jellemzően hosszabb hagyományra tekint vissza. Az eredetileg a helyi jeles napok, egyházi alkalmak megünneplését szolgáló események napjainkra sokkal szélesebb társadalmi merítéssel próbálnak a lakosok igényeinek megfelelni. Ennek eredményeként egyre több településen szerveznek programokat célzottan a gyerekeknek, a kisgyermekes családoknak vagy az időseknek [31]. Más szempontból nézve, miként arra az olasz ColleMarathon önkéntes szervezői is bebizonyították, egy eredetileg szúk kör számára szervezett sportesemény is fejleszthető olyan módon, hogy közben az alapítók eredeti elveit is meg lehet őrizni. A vizsgált esetben ezek az elvek a helyi értékek népszerüsítése, a szervezésbe bekapcsolódó települések szokásainak, lakosságainak bemutatása, a tájkép értékeinek kommunikálása, amely sikeresen és eredményesen megvalósul nemcsak a versenyzők, hanem családtagjaik, ismerőseik körében is [2]. 
Jelen cikk arra az igen tág kérdésre keresi a választ, hogy miként lehet növelni a jólétet és az életszínvonalat a vidéki területeken. A kérdésre adható egyik lehetséges válasz éppen a különböző rendezvények szervezésének a köre, amely olyan szórakozási, kikapcsolódási és feltöltődési lehetőséget biztosíthat a vidéki térségek lakói számára, amely korábban jellemzően inkább a városias területeken volt elérhető.

\section{A vidék fogalma és problémái}

A vidék fogalmának meghatározása hosszabb ideje foglalkoztatja a tudományos közvéleményt. A vidék, a vidékiség ugyanis több tudományterület és tudományág szempontjából is relevanciával bíró fogalom, amelyet a szociológiától a gazdaságtudományig számos terület használ, részben eltérő tartalommal. A gazdaságtudományok és a vidékfejlesztés szempontjából kiemelkedő relevanciával bír a fogalom európai uniós támogatásokkal is összefüggésbe hozható jelentéstartalma [35]. A vidék, vidékiség jelentésével kapcsolatos legfontosabb változások az agrárium modernizációjával vették kezdetüket. Ezek mellett a kialakult vidékképet tovább árnyalja a városokból kiköltöző népesség megjelenése [35]. Az ő megjelenésükkel a vidéki népesség körében jelentős változások veszik kezdetüket, a fejlődési tendenciák más irányba mutatnak, egyebek mellett az eltérő fogyasztási szokások, szolgáltatási szükségletek és igények okán. Emellett a szuburbanizációs folyamatok eredményeként változik a vidék gazdasága, amire igen szembeötlő példa az agrárium jelentőségének és eltartóképességének drasztikus visszaesése [42].

Kovács et al. (2015) [36] tanulmányukban összefoglalják a vidék, mint fogalom meghatározásával kapcsolatos eredményeket. Eszerint a vidék fogalmának meghatározását több szempontból is meg lehet adni, amelyek komplexitása igen nagy változatosságot mutat. A legegyszerúbb meghatározások még pusztán annyit hangsúlyoznak, hogy vidéknek tekinthetünk minden olyan területet, amely egyébként nem felel meg a várossá minősítés feltételeinek. Számos olyan meghatározás is született az elmúlt évek során, amely a vidék fogalmát egy meghatározott, négyzetkilométerenkénti vagy négyzetmérföldenkénti népsürüségi határhoz kötötte, vagyis a meghatározott értéket el nem érő területek számítanak ebben az esetben vidéknek. Az elmúlt évek során azonban egyre több olyan vidék-meghatározás látott napvilágot, amely a vidék fogalmához a fejlesztések szempontjából, vagyis a fejlesztési lehetőségek, igények és szükségszerüségek irányából közelít. Kis (2011) [33] tanulmányában ugyanakkor kiemeli, hogy a vidék fogalmának meghatározása egyáltalán nem öncélú tevékenység, hanem a jelentéstartalom egységes értelmezésének kerete teremthető meg ennek folyományaként. Mindennek jelentőségét fokozza, hogy a fejlesztési lehetőségek és igények meghatározása során éppen ennek a fogalomnak az alkalmazására kerül sor, vagyis annak tartalma jelentős befolyást gyakorol a fejlesztési politikák alakulására is.

Short (2006) [57] vizsgálatai szerint a vidékkép napjainkra egyre változatosabbá válik. A folyamat eredményeként a korábban a pozitív elemek által uralt kép mára sokkal színesebbé vált, a negatív tartalmi elemek egyre hangsúlyosabb megjelenésének eredményeként. Ez a tendencia hazánkban már évtizedek óta megfigyelhető. Szelényi (1973) [6o] a vidéki területekkel kapcsolatos kutatásában kiemeli a területi egyenlőtlenségek jelentőségét, amely az életkörülmények pozitív vagy negatív jellegével kapcsolatban a földrajzi elhelyezkedés kiemelt szerepét hangsúlyozza. Horeczki (2014) ugyanakkor a vidéki térségek, a kistelepülések problémái között munkaerőpiaci, infrastrukturális és gazdasági jellegűeket is elkülönített, amelyeket Vasárus (2016) [63] szerint a szuburbanizációs folyamatok is erősítenek. Ez utóbbi tendenciák jellemzően a nagyvárosok környékén fordulnak elő, központi elemüket pedig a nagyvárosból párhuzamosan kiáramló tehetős és leszakadó rétegek egyidejü vidéki megjelenése által generált konfliktusok jelentik.

Nagy et al. (2015) [49] a marginalizáció vizsgálata során megállapították, hogy a vidéki népesség tagjai számos szempontból nézve megtapasztalhatják a kiszorítottság helyzetét. A szociális, így munkaerőpiaci és gazdasági körülmények által befolyásolt marginális társadalmi pozíció kapcsán kiemelendő a vidéki térségek centrumoktól mért földrajzi távolsága is. Ennek eredményeként a vidéken élő, leszakadó népesség helyzetét a földrajzi körülmények is negatívan befolyásolják. Ezt a tendenciát tovább erősíti a vidéki térségek és az egészség közötti kapcsolat változása. Míg a 20. század közegészségügyi-higiéniás és orvostudományi forradalma előtt a vidéki térségek számítottak az egészségi állapotra pozitívan ható területeknek, hiszen a friss levegő, a fizikailag aktív élet természetesen is javítják az emberek egészségi állapotát; addig napjainkra a helyzet gyökeresen 
megváltozott. Ma a vidéki egészséggel kapcsolatos lehetőségek alulmúlják a városokban elérhetőeket, hiszen a rendelkezésre álló orvosi és egyéb egészségügyi szolgáltatások jellemzően sokkal ritkábban érhetőek el, kínálatuk sokkal szegényesebb, illetve jellemzően az egészségügyi infrastruktúra is elmaradásokat mutat [56].

Lennert - Farkas (2019) [43] előrejelzése szerint a vidéki népesség fogyatkozása az elkövetkező 30 évben továbbra is folytatódni fog. Az ország népessége, különösen pedig a vidéken élő lakosság elöregedése várhatóan folytatódni fog, ráadásul a rurális térségek a népvándorlási folyamatokból is vesztesen jönnek majd ki. Előreláthatólag egyedül a Budapest környéki agglomeráció kistelepülései körében számíthatunk számottevő, mérhető népességnövekedésre. A fentiek szerint a magyarországi tendenciák hosszabb távon sem esnek majd egybe a globális népesedési trendekkel [21]. A vidéki térségekben ugyanakkor nemcsak a népesség fogyása, hanem elöregedése is jelentősen hat majd az életkörülményekre. Számos kutatás foglalkozik a vidéken élő világnépesség elöregedésével, illetve a vidéken élő idősek élethelyzetével. Kína tengerparti területein a kistelepüléseken lakó idősek gyakorta kénytelenek magas életkorukban is aktívan munkát vállalni vagy a mezőgazdaságban, vagy a háztartásban, ahol elsősorban a városokba települő fiatalok szerepét kénytelenek átvenni. A szociális ellátórendszer hiányosságai, illetve részben múködési sajátosságai folytán sok idős kénytelen igénybe venni fiatalabb családtagjai segítségét a mindennapi megélhetés biztosításához is [8]. A munka és a magánélet közötti egyensúly fenntartása az újabb kutatások szerint egyébként életkortól függetlenül is - jelentősen kihat az egészségi állapotra [14]. Mindezt azért is szükséges hangsúlyozni, mert Kelet-Közép-Európában a vidéki térségekben számos olyan problémát kell megoldani, amelyek egymásra hatva, egymást erősítve képesek a negatív tendenciákat fokozni. A térségre általánosságban, noha országonként eltérő mértékben jellemző, hogy a vidéki területeken jelentős problémát okoz az elöregedés, aminek okaként nemcsak az alacsony születő gyermekszám, hanem az elvándorlás is feltárható. A vidék ugyanakkor csak korlátozottan képes lehetőségeket kínálni lakóinak, hiszen ezekben a térségekben jellemzően rosszabb az infrastrukturális hálózat kiépítettsége és állapota - különösen igaz ez a közlekedési infrastruktúra helyzetére és a tömegközlekedés szolgáltatási színvonalára, így kiemelten járatsűrűségére, ami megnehezíti például az ingázást -. az egészségügyi és szociális intézmények elérhetősége, illetve a létező álláshelyek változatossága [3]. Kelet-Közép-Európában a mezőgazdaság, illetve földrajzi fekvéstől függően a halászat és az erdőgazdálkodás jelentősége a vidéki foglalkozási szerkezetben továbbra is meghatározó. Ki kell emelni továbbá a primer szektor által előállított termények, alapanyagok feldolgozására épülő iparágak jelenlétének jelentőségét is a foglalkoztatásban, illetve a mezőgazdaság általános gazdasági jelentőségét is a vidéki térségekben [45, 58, 22, 23, 44, 27, 18, 20, 39, 19, 37, 59].

A primer szektor jelentősége ugyanakkor a rendszerváltás óta csökkent a vidék gazdaságában, ennek helyére azonban sokkal kisebb mértékben tudtak belépni az újabb alapítású vállalkozások, illetve az újabb területeken aktív cégek [30]. Szükséges ugyanakkor azt is hangsúlyozni, hogy a felsorolt problémák, úgy mint a vidék magára hagyottsága, az elszegényedés, a marginalizáció, az elöregedés vagy éppen az agrárium túlsúlya a helyi gazdaságban, mind létező problémák, azonban nem feltétlenül érintenek minden vidéki térséget, illetve nem feltétlenül jelentkeznek egyidejúleg. Az egyes vidéki területek érintettsége a felsorolt problémák kapcsán nagyban függ azok földrajzi fekvésétől, illetve a tájszerkezettől, tájképtől is [62], miközben már évtizedek óta megfigyelhető, hogy egyre több vidéki térség indul meg az urbanizáció útján [1]. A vidék fejlődését a jövőben elsősorban az innováció, a fenntartható fejlődés, a vidéki terek versenyképessége, a tudásra alapozott rurális társadalom kialakulása és megerősödése, továbbá az új funkciók elérhetőségére vonatkozó igények elfogadása, illetve maguknak az új funkcióknak a megtelepedése kell, hogy meghatározza [61, 32]. A felsorolt alapelveket leginkább a nyitottság köti össze, vagyis azon térségek lehetnek sikeresek a jövőben, amelyek nyitottan állnak a társadalmi és gazdasági változások folyamataihoz.

\section{Lehetôségek a vidéki területek élhetőségének fokozására}

A vidéki térségek fejlődését igen kézenfekvő a helyi közösség identitásának erősítése útján fejleszteni. Jelen fejezet két részében két különböző rendezvénycsoport lehetőségeit vizsgálom a helyi közösségek, a kistelepülések fejlesztése szempontjából. Természetesen az ismertetett rendezvénytípusok gazdasági hatással is bírnak, azonban jelentőségük a lakóhely és a lakosság között kialakuló érzelmi kapocs erősítésében is meghatározó. 
Economica XII. Új évf., 1-2. sz. (2021)

ISSN 2560-2322

\subsection{Szabadidős és kulturális rendezvények vidéken}

Amennyiben sikerre szeretnénk fejleszteni egy-egy vidéki térséget, mindenképpen szükséges a helyi kulturális örökség, a néphagyományok és szokások vizsgálata, feltérképezése. Ezen ismeretekre alapozva ugyanis olyan fejlesztési lehetőségek alakulhatnak ki, amelyek egyfelől szervesen kötődnek a helyben élő lakossághoz, másfelől pedig erősíthetik a lokálpatrióta érzéseket, így a kötődést a lakóhelyhez. Az egyes rurális térségek pozicionálásában a helyi folklór és kulturális értékek, örökségek mellett kiemelt szerep jut a helyi iparnak, kézmúvesiparnak is. A felsoroltakat értékként lehet kommunikálni a látogatók irányába, ami segít a vidéki térségek gazdasági és társadalmi fejlődésének fokozásában [55]. Pusztai (2007) [54] kiemelése szerint az egyes településekre, kisebb térségekre lokálisan jellemző értékek segítségével olyan körülményeket lehet teremteni, amelyet a vidéki térség emblematikus jellegzetességeként gazdasági szempontból is hasznosítani lehet. Csurgó - Szatmári (2014) [10] kiemelése szerint az 1990-es évek közepétől volt megfigyelhető az a szemléletmódváltás a vidékfejlesztésben, amely a külső körülményekre és erőforrásokra épülő fejlesztési stratégiák helyett inkább a helyi jellegzetességekre, helyi tradíciókra támaszkodva segíti egy-egy térség fellendülését. Ez a szemléletmód az Európai Unió vidékfejlesztési politikájában is egyre nagyobb szerephez jut, ahol nemcsak a tagállamok, hanem a régiók is jelentős szerephez jutnak ezen a téren [17].

Csurgó (2016) [11] vizsgálatában két olyan, nagy hagyományokkal bíró magyar vidéki vásárt hasonlított össze, amelyek a rendszerváltás előtti alapításukat követően hasonló céllal, a helyi fazekasság termékeinek bemutatását szem előtt tartva működtek hosszú ideig. A rendszerváltást követően azonban a két rendezvény eltérő fejlődési modellt követve tudta megtartani jelentőségét, hiszen az egyik úgy jelent fontos kereskedelmi fórumot, hogy közben elsősorban a település és a térség turisztikai vonzerejét növeli, míg a másik elsődleges célja az otthont adó település lakosságmegtartó képességének fokozása azáltal, hogy évről évre színes programként jelentkezik a helyiek életében. Mindkét rendezvényben közös ugyanakkor, hogy a lokális identitás erôsítése és kihangsúlyozása egyértelműen értékként kommunikálja a házigazda településhez, térséghez való kötődést. Az identitás hangsúlyozása elsősorban a kereskedelmi-gazdasági tevékenységet kísérő kulturális programkínálat megszervezése útján valósulhat meg.

Magyarországon a különböző, uniós és kormányzati forrásokból megvalósuló, a vidéki térségek fejlődését célzó programok során prioritás, hogy a települések és térségek fellendülését olyan módon segítsék a támogatások, hogy az a turizmusra is ösztönzőleg hasson, illetve támogassa a helybe érkező befektetéseket is. Ez a települések múködésére is ösztönzőleg ható tendencia jelentősen javítani tudja a helyben élők életminőségét is, miközben a turisták körében is attraktívabbá tudja tenni az egyes desztinációkat [47]. Ennek keretében a helyi identitást megteremtő és erősítő hatással bíró kulturális rendezvények és szervezetek múködését is támogatni lehet, amelyek között megkülönböztetünk önszerveződőeket és az intézményesített kultúra helyi letéteményeseit is. Az érintett szervezetek és csoportok nemcsak helyben képesek a település élhetőségét javítani, de más településekre, más országokba látogatva a potenciális vendégek és látogatók figyelmét is fel tudják hívni a helyi értékekre [7].

Az egyes települések életében a turisztikai attrakcióknak a helyi lakosság szempontjából is jelentősége van. Az ilyen rendezvények ugyanis növelni tudják a település élhetőségét azáltal, hogy minőségi lehetőségeket kínálnak a települések polgárainak is a szabadidő eltöltésére. A rendezvények jellemzően valamilyen helyi hagyományhoz vagy értékhez kapcsolódnak [29]. A szabadidő minőségi eltöltése számos formában történhet, egyebek mellett lehetőség nyílik olyan intézmények meglátogatására, amelyek kulturális értékeket közvetítenek, illetve amelyek a társas szabadidőtöltés különböző formáinak kedveznek. Projektek segítségével az ilyen lehetőségek száma gyarapítható [40].

Egy-egy település élhetőségére, így a vidéki térségek népességmegtartó képességére több körülmény is jelentős hatást gyakorol. Az élhetőség szintjének alakulása részben annak is függvénye, hogy az állami jólléti politikák milyen hatást tudnak helyben gyakorolni, ezáltal pedig közvetve a helyben élő lakosság szubjektív jóllétére. Ehhez első körben a már meglévő jólléti rendszerek keretein belül kell megtenni mindent annak érdekében, hogy a polgárok jólléte javulhasson [41].

A fentiek alapján a helyi kulturális és szabadidős fejlesztések bevezetésével kettős cél valósítható meg a vidékfejlesztéssel összefüggésben. Egyfelől növelhető a vidéki térségek 
népességmegtartó ereje annak eredményeként, hogy a településeken a szubjektív lakossági jóllét szintje fokozódik. Másfelől a turisztikai relevanciával is bíró közösségi fejlesztések eredményeként egyre fokozódhat a térségekbe irányuló célturizmus mértéke is. A növekvő vendégszám folyományaként a vidéki térségek gazdasága erősödhet, újabb munkahelyek jöhetnek létre, ami ismételten a helyben élő lakosság jólléti érzetének növekedését eredményezheti, illetve emelkedhet a vidéki térségek népességmegtartó ereje is.

\subsection{Sportrendezvények vidéken}

A sportrendezvények szervezésével, hasonlóan a turisztikai és kulturális beruházásokhoz, ismételten többes célt lehet megvalósítani a vidékfejlesztés területén. A jelentős versenysportesemények és a tömegsport események komoly hatást gyakorolhatnak a rendező települések és országok gazdaságára. Ennek megfelelően a sportrendezvények megtartásával a vidéki térségek népességmegtartó ereje is növekedhet. A sportesemények gazdasági hatásai között mindenképpen ki kell emelni a turizmust ösztönző hatást. Attól függően, hogy milyen rendezvényről van szó, akár világszinten is vonzó lehet a versenyzők és a játékosok számára. Itt természetesen nem feltétlenül kell a legnagyobb sportrendezvények megrendezésére gondolni, noha az Olimpia, illetve egy-egy kiemelkedő népszerűségű sportág Világ- vagy Európa-bajnoksága jelentős turisztikai hatást generál. Ehhez képest egy-egy ennél nagyságrendekkel kisebb volumenư, akár nem is versenysportolók számára megrendezett esemény is számos turistát vonzhat a rendezés színhelyére. A jelentős versenysport-események gazdasági hatásainak egy része a médiasugárzáshoz kapcsolódik: a közvetítési jogok értékesítése komoly bevételi forrást jelent a házigazda országoknak és városoknak is. Ezen túlmenően a nagy sportrendezvények megszervezéséhez jellemzően olyan, például infrastrukturális hatások is társulnak, amelyek a késóbbiekben lesznek képesek segíteni a térségek gazdasági fejlődését. Mindez azért is rendkívül előnyös, mert a fejlődéshez szükséges, például közlekedési infrastruktúra megléte a vidéki térségek fejlődéséhez elengedhetetlen. A sportrendezvények társadalmi hatásai közül ugyanakkor mindenképpen ki kell emelni a lakosság körében növekvő sportolási hajlandóságot, amely képes hozzájárulni a népesség egészségi állapotának javulásához. Amennyiben a lakosság egészségi állapota javul, az egyértelműen jót tesz a népesség szubjektív jólléthez füződő érzéseinek is. Az emelkedő sportolási aktivitás folyományaként a sportszerek és sporteszközök fogyasztása is növekedhet, ezzel fokozva a helyi gazdaság teljesítóképességét. Emellett mindenképpen ki kell hangsúlyozni, hogy a sportrendezvények lebonyolításához jellemzően igen kiterjedt önkéntes munkavégzés is társul a lakosság részéről, ami növeli a helyi identitásérzetet, ehhez kötődően pedig - ismételten - a szubjektív jóllét érzését. Ezen hatások együttesen mind képesek hozzájárulni a vidéki térségek népességmegtartó erejének fokozásához [5, 24, 25, 48, 26, 15, 16].

A vidék fejlődése szempontjából kiemelt jelentőséggel bír a népességmegtartó erő fejlődése. Amennyiben a lakosság elköltözik egy-egy területről, ott a fejlődés esélye voltaképpen megszünik, a gazdasági visszaesés hatására pedig fokozatosan elnéptelenedik egy-egy település. A vidék fejlődése szempontjából kiemelt jelentősége van a magasan képzett rétegek jelenlétének, csakhogy annak érdekében, hogy diplomát szerezhessenek, a települések legtehetségesebb fiataljai rendre nagyvárosokba költöznek hosszabb-rövidebb időre, ami önmagában nem jelentene problémát, azonban onnan visszaköltözni már korántsem mindegyikük lesz hajlandó. Ez azt eredményezi, hogy a rurális térségek éppen a legmagasabban képzett, éppen ezért a helyi fejlődést leginkább elősegíteni képes tagjait veszíti el, illetve a városi területek éppen a legmagasabban képzett lakosokat vonzzák el vidékről. Ennek eredményeként több kutatás is foglalkozott annak vizsgálatával, hogy milyen körülmények befolyásolják a városokban tanuló, de egyébként vidékrool származó hallgatók hazaköltözési hajlandóságát. Ezek eredményeként megállapításra került, hogy a legfontosabb gazdasági és szociális körülmények, így a lakhatás és a munkavállalás kérdései, a minőségi élet folytatására elegendő jövedelem rendelkezésre állása mellett kiemelt jelentősége van a helyi sportolási lehetőségek meglétének. A hallgatók ugyanis, akik egyetemi éveik alatt jellemzően nagyfokú érdeklődést mutatnak a testmozgás, az aktív és passzív sportfogyasztás iránt, munkavállalóként is kiemelt jelentőséget tulajdonítanak annak, hogy megfelelő sportolási lehetőségek legyenek elérhetőek. Ez összhangban van azokkal a véleményekkel, amelyek a sportok 
szubjektív jóllét megítélésében játszott szerepét hangsúlyozzák. Az elérhető sportok köre, illetve az igényelt sportok köre is igen változatos lehet, hiszen a mindennapi testedzéshez szükséges kondícionáló termek mellett a különböző csapatsportok, labdajátékok elérhetőségének is nagy jelentősége van. Emellett a különleges sportok helyi elérhetősége is vonzó lehet a diplomások számára. A családalapítást tervező fiatalok számára annak is relevanciája van, hogy a gyerekek számára milyen sportolási lehetőségek adottak egy-egy településen $[51,4,12,38,52,13,14,46,53$, 6].

Összességében megállapítható, hogy a vidéki térségek élhetőségére jelentős pozitív hatást gyakorolhat, amennyiben ott sporttal kapcsolatos fejlesztések történnek. Ez részint hat a helyben lakó népesség egészségére, részben pedig a település vonzerejére is. Ma a magasan képzett fiatal népességet nem pusztán a magas jövedelemmel lehet megtartani, hiszen a településválasztási preferenciákra olyan, a mindennapi életvezetésre is ható tényezők is befolyást gyakorolnak, mint például a sportolási lehetőségek elérhetősége.

\section{4. Összefoglalás}

Cikkemben a vidéki térségek problémáit vizsgáltam komplex megközelítésben, illetve részben összefoglaltam a szakirodalomban jelenleg a vidéki kihívások kezelésére tett javaslatokat. Szekunder adatfeltárásom eredményeként megállapítható, hogy a vidéki területeken jelentkező nehézségek orvosolhatóak, azonban ezek megoldása - természetesen - igen összetett cselekvés-sorozatokat kíván az államtól, az önkormányzatoktól és maguktól a lakosoktól is.

Jelenleg a korábbi pozitív vidékkép helyét egyre több helyen átvette a kihívásokkal küzdő vidék tudományos igényű bemutatása. A vidék a világ számos helyén egy, a lehetőségek hiányát jelentő, gazdasági nehézségektől küzdő, a fokozatos elnéptelenedéstől szenvedő kategória lett, amelyet a jelentős vonzerővel rendelkező urbánus területek ellentettjeként írnak le. Noha az ilyen sötét hangulatú, pesszimista leírások olykor túlzóak lehetnek, a vidék fejlődésének elősegítése érdekében okvetlenül be kell látni, hogy a rurális térségek valóban kihívásokkal küzdenek, amelyek megfelelő kezelés híján komoly krízissé alakulnak. A vidéki népességszám csökken, a gazdasági kilátások borúsak, ami nem kis részben az aktív és versenyképes munkaerő, illetve a megfelelő munkahelyek hiányára vezethető vissza. Az elmúlt évtizedekben Kelet-Közép-Európában a vidéki térségek nemcsak infrastrukturálisan, de közszolgáltatásaikat tekintve is leszakadtak az urbánus övezetektől. Ennek folyományaként a korábban az egészséggel asszociált vidéki életforma helyét mára jellemzően átvette az orvoshiánytól küzdő vidék kategóriája.

A vidék fejlődésében azonban jelentős lehetőségek tárulnak elénk. A mezőgazdasági szektor globális jelentősége a jövőben várhatóan fokozódik, ahogyan a világnépesség növekszik, illetve ahogyan a fogyasztási szokások változnak. Ez komoly lehetőségeket jelent a hagyományos vidéki ágazatok, így a mezőgazdasági termelés és az erre épülő feldolgozóipar fejlődésének. Ennek során azonban szem előtt kell tartani, hogy a 21. században már más szemlélettel kell a termeléshez és a feldolgozáshoz is hozzálátni, ezekben a szektorokban is növekszik a szaktudás jelentősége, ami mindenképpen szükségessé teszi a tudásátadás formalizálását.

A vidék fejlődése nem kis részben azon is múlik, hogy a települések élhetőségét mennyire tudja fokozni a kormányzat és az érintett helyi önkormányzatok által bevezetett intézkedések sora. Cikkemben két olyan terület lehetőségeit vizsgáltam részletesebben, amelyek képesek a települések élhetőségének, így a lakosság jóllétének, ennek folyományaként pedig a térségek népességmegtartó erejének fokozására. Kulcsjelentőséggel bír ebben a kérdésben a helyi identitás erősítése és értékként közvetítése a lakosság és a turisták irányába. Ez részint a településeken elérhető kulturális és szabadidős tevékenységek, illetve sportolási lehetőségek fokozásával is elérhető.

\section{Köszönetnyilvánítás:}

A kutatás az EFOP3.6.3-VEKOP-16-2017-00007 - "Tehetségből fiatal kutató" - A kutatói életpályát támogató tevékenységek a felsőoktatásban. címú projekt keretében valósulhatott meg. 


\section{Irodalomjegyzék}

[1] Antrop, M. (2000): Changing patterns in the urbanized countryside of Western Europe. Landscape Ecology, 15. pp. 257-270.

[2] Aureli, S. - Graziano, H. (2020): When ethical values drive the creation and development of sporting events. In: Fotiadis, A. - Vassiliadis, C. (szerk.): Principles and practices of small-scale sport event management. IGI Global, Hershey. pp. 217-232.

[3] Bański, J. (2019): Spatial differences in the transformation processes taking place in rural areas of East-Central Europe. In: Bański, J. (szerk.): Three decades of transformation in the East-Central-European Countryside. Springer, Cham. pp. 3-20.

[4] Bartha, É. J. - Müller, A. - Bácsné Bába, É. (2018): A fitnesz fogyasztók sportlétesítmény-választását befolyásoló legfőbb szempontok alakulása életkor szerint. Selye E-Studies, Vol. 9, No. 1. pp. 4-12.

[5] Bácsné Bába, É. - Szenderák, J. - Harangi-Rákos, M. (2019): A magyarországi sportszolgáltató vállalkozások gazdasági helyzete 2016-ban. Taylor Gazdálkodás- és Szervezéstudományi Folyóirat, Vol. 11, No. 3-4. pp. 5-14.

[6] Bácsné Bába, É. - Ráthonyi, G. - Pfau, C. - Müller, A. - Szabados, Gy. N. - Harangi-Rákos, M. (2021): Sustainability - Sport - Physical Activity. International Journal of Environmental Research and Public Health, Vol. 18, No. 4. p. 1455 .

[7] Bene, V. (2014): Derecske kulturális értékeinek szerepe a helyi közösség életében. Metszetek, 2014/3. pp. 183-195.

[8] Chen, N. - Chen, J. - Ko, P-C. (2021): Active aging in the countryside: Space, place and the performance of leisurework lifestyles in contemporary rural China. Population, Space and Place, 2021; e2429. https://doi.org/10.1002/psp.2429 pp. 1-15.

[9] Cividino, S. - Halbac-Cotoara-Zamfir, R. - Salvati, L. (2020): Revisiting the „City Life Cycle”: Global urbanization and implications for regional development. Sustainability 2020, 12(3), 1151. https://doi.org/10.3390/su12031151 pp. 1-18.

[10] Csurgó, B. - Szatmári, A. (2014): Vidéki kultúra, helyi közösség és lokális identitás. A kulturális örökség szerepe a lokális identitásépítésben és a helyi közösségfejlesztésben Hajdúdorogon és Hajdúhadházon. Metszetek, 2014/3. pp. 33-51.

[11] Csurgó, B. (2016): Vásári forgatag, vidékimázs, turizmus és helyi közösség: a mezőtúri Túri Vásár és az őriszentpéteri Őrségi Vásár esete. In: Forray, R. K. - Kozma, T. - Molnár, E. (szerk.): Mezőváros új szerepben. HTSART-ÚMK, Budapest. pp. 163-182.

[12] Dajnoki, K. - Szabados, Gy. N. - Kulcsár, G. - Kőmíves, P. M. - Bácsné Bába, É. (2018): „Visszatérni vidékre” Hallgatói vidékképek kvalitatív megközelítésben. International Journal of Engineering and Management Sciences, Vol. 3, No. 5. pp. 204-216.

[13] Dajnoki, K. - Halász, P. - Kőmíves, P. M. - Szabados, Gy. N. - Bácsné Bába, É. (2019): Airsoft kilátások: sport és szervezeti oldal. Hadtudomány: A Magyar Hadtudományi Társaság Folyóirata, Vol. 29, E-szám. pp. 105-115.

[14] Dajnoki, K. - Kőmíves, P. M. - Szabados, Gy. N. - Bácsné Bába, É. (2020a): Factors influencing well-being at work. Hadtudomány: A Magyar Hadtudományi Társaság Folyóirata, Vol. 30, E-szám. pp. 183-197.

[15] Dajnoki, K. - Fenyves, V. - Bácsné Bába, É. - Kómíves, P. M. - Szabados, Gy. (202ob): Sportokkal foglalkozó civil szervezetek jellegzetességei, különös tekintettel a foglalkoztatásra. International Journal of Engineering and Management Sciences, Vol. 5, No. 1. pp. 750-761.

[16] Dajnoki, K. - Szabados, Gy. N. - Bács, Z. - Bácsné Bába, É. - Kőmíves, P. M. (2021): Sport, nonprofitok, civilek: Foglalkoztatás és önkéntesség vizsgálata Magyarországon és Romániában. Régiókutatás Szemle, Vol. 6, No. 1. pp. 90101.

[17] Fehér, I. - Kujáni, K. O. (2011): A vidéki hálózatok tevékenysége az Európai Unióban, kételyek és esélyek. Gazdálkodás, Vol. 55, No. 3. pp. 296-308.

[18] Fenyves, V. - Pető, K. - Harangi-Rákos, M. - Szenderák, J. (2019): A Visegrádi országok mezőgazdasági vállalkozásainak gazdasági és pénzügyi helyzete. Gazdálkodás, Vol. 63, No. 6. pp. 459-473.

[19] Fenyves, V. - Pető, K. - Szenderák, J. - Harangi-Rákos, M. (2020): The capital structure of agricultural enterprises in the Visegrad countries. Agricultural Economics - Zemedelska Ekonomika, Vol. 66, No. 4. pp. 160-167.

[20] Fróna, D. - Kőmíves, P. M. (2019): A mezőgazdasági munkaerő sajátosságai. Gazdálkodás, Vol. 63, No. 5. pp. 361380.

[21] Fróna, D. - Szenderák, J. - Harangi-Rákos, M. (2019): The challenge of feeding the world. Sustainability 2019, 11(20), 5816. https://doi.org/10.3390/su11205816

[22] Harangi-Rákos, M. - Szabó, G. (2012): The economic and social role of private farms in Hungarian agriculture. APSTRACT - Applied Studies in Agribusiness and Commerce, Vol. 6, No. 5. pp. 33-41.

[23] Harangi-Rákos, M. - Szabó, G. - Popp, J. (2013): Az egyéni és társas gazdaságok gazdasági szerepének fóbb jellemzői a magyar mezőgazdaságban. Gazdálkodás, Vol. 57, No. 6. pp. 532-543.

[24] Harangi-Rákos, M. - Bács, Z. - Szenderák, J. (2019a): A 2012-es londoni nyári olimpia társadalmi hatásainak elemzése. In: Bácsné Bába, É. - Müller, A. (szerk.): „Mozgással az egészségért”. A fizikai aktivitás jelentősége a jövő munkavállalóinak egészségmegőrzésében. Debreceni Egyetem, Debrecen. pp. 161-175.

[25] Harangi-Rákos, M. - Pöszmet, T. - Nagy, A. Sz. (2019b): A Formula 1 gazdasági hatásai. In: Balogh, L. (szerk.): Sport és társadalom. Debreceni Egyetem Sporttudományi Koordinációs Intézet, Debrecen. pp. 83-92.

[26] Harangi-Rákos, M. - Nagy, A. Sz. - Pfau, C. - Müller, A. - Szabados, Gy. N. - Bácsné Bába, É. (2020): A sporteszközök piacának helyzete. Acta Carolus Robertus, Vol. 10, No. 2. pp. 69-84.

[27] Herman, S. - Körösparti, P. - Kőmíves, P. M. (2018): A magyar agrár-felsőoktatás aktuális helyzete. International Journal of Engineering and Management Sciences, Vol. 3, No. 4. pp. 263-281. 
[28] Horeczki, R. (2014): A dél-dunántúli kisvárosok a fejlesztési tervek tükrében. DETUROPE - The Central European Journal of Regional Development and Tourism, Vol. 6, No. 3. pp. 97-111.

[29] Horváth, Zs. - Sánta, F. - Kóródi, M. (2015): A szolnoki Gulyásfesztivál szerepe Szolnok város turizmusában és vendégkörének változása. Economica, Vol. 8, No. 2. pp. 57-64.

[30] Jankovics, K. (2018): Az individuum biztonsága vidéki térben. Studia Mundi - Economica, Vol. 5, No. 1. pp. 13-23.

[31] Jágerová, M. (2020): Inspirational sources of cultural and social events and celebrations in current rural environment (on the example of the villages of Vlachovo, Soblahov, Malé Dvorníky, and Liptovská Teplička). Národopisná Revue (Journal of Ethnology), 2020(3). pp. 223-235.

[32] Katekhaye, D. - Uuld, A. - Magda, R. (2018): Rural Entrepreneurship Motivation: A Prospect of Entrepreneurs in Hungary In: Frankovský, M; Dobrovič, J; Fedorko, R (szerk.) Management 2018: Management and the world in motion, challenges, opportunities and threats Presov, Szlovákia : University of Prešov 888 p. pp. 823-828. , 6 p.

[33] Kis, K. (2011): A vidék és a vidéki térségek meghatározásának európai vonatkozásai. (Történeti áttekintés az Európai Bizottság város-vidék tipológiája apropóján.) Jelenkori Társadalmi és Gazdasági Folyamatok, Vol. 6, No. 1-2. pp. 105112.

[34] Kovách, I. (2010): A jelenkori magyar vidéki társadalom szerkezeti és hatalmi változásai. MTA doktori értekezés. Magyar Tudományos Akadémia, Budapest.

[35] Kovách, I. (2012): A vidék az ezredfordulón. A jelenkori magyar vidéki társadalom szerkezeti és hatalmi változásai. Argumentum - MTA Társadalomtudományi Kutatóközpont (Szociológiai Intézet), Budapest.

[36] Kovács, A. D. - Farkas, J. Zs. - Perger, É. (2015): A vidék fogalma, lehatárolása és új tipológiai kísérlete. Tér és Társadalom, Vol. 29, No. 1. pp. 11-34.

[37] Kovács, E. V. - Harangi-Rákos, M. (2020): Cities vs. the countryside - Pros and cons of urban and rural life. Annals of the University of Oradea Economic Science, Vol. 29, No. 1. pp. 530-539.

[38] Kőmíves, P. M. - Szabados, Gy. N. - Kulcsár, G. - Bácsné Bába, É. - Fenyves, V. - Dajnoki, K. (2018): „Visszatérni vidékre.” A sport megtartó ereje. International Journal of Engineering and Management Sciences, Vol. 3, No. 4. pp. 292-307.

[39] Kőmíves, P. M. - Pilishegyi, P. - Novák, N. - Nagy, A. Sz. - Körösparti, P. (2019): The role of the higher education in the development of the agriculture. International Journal of Information and Education Technology, Vol. 9, No. 9. pp. 607-612.

[40] Kővári, E. - Pásztor, J. - Raffay-Danyi, Á. (2021): A Pannon Egyetem közösségének kultúrafogyasztása, az érzelmi és kulturális intelligencia összefüggése: Veszprém 2023 Európa Kulturális Fővárosa. Vezetéstudomány, Vol. 52, No. 4. pp. 48-62.

[41] Lakócai, Cs. (2020): Jóléti állami modellek és jóllétalapú klaszterek az Európai Unió országaiban: van-e átfedés? ELKH Közgazdaság- és Regionális Tudományi Kutatóközpont Világgazdasági Intézet Múhelytanulmányok 140. 2020. december. p. 28 .

[42] Lennert, J. (2019): Vidéki újrastrukturálódás a visegrádi országokban - egy angolszász fogalom hazai adaptációjának kérdőjelei. In: Farkas, J. Zs. - Kovács, A. D. - Perger, É. - Lennert, J. - Hoyk, E. - Gémes, T. (szerk.): Alföldi kaleidoszkóp: A magyar vidék a XXI. században. Tanulmányok a 70 éves Csatári Bálint köszöntésére. MTA KRTK Regionális Kutatások Intézete, Kecskemét. pp. 197-205.

[43] Lennert, J. - Farkas, J. Zs. (2019): Az utolsó majd lekapcsolja a villanyt? A magyar vidék jövője különböző demográfiai forgatókönyvek tükrében. In: Kőszegi, I. R. (szerk.): III. Gazdálkodás- és Menedzsment Tudományos Konferencia: Versenyképesség és Innováció. Neumann János Egyetem, Kecskemét. pp. 77-83.

[44] Magda, R. (2017): The role of human resource management in the rural area in Hungary Social and Economic Revue/Socialno-Ekonomicka Revue, $15: 1$ pp. 33-38.

[45] Magda, R - Marselek, S (szerk.) (2010): Vidékgazdaságtan I: A vidékfejlesztés gazdasági folyamatai. Budapest, Magyarország : Szaktudás Kiadó Ház, 297 p. ISBN: 9789639935426

[46] Maklári, E. - Bartha, É. J. (2020): Sportolási szokások a különböző életszakaszokban. Gazdálkodástudományi Közlemények, Vol. 8, No. 1. pp. 43-50.

[47] Molnár, N. - Egedy, T. (2020): Turizmusfejlesztéssel a hátrányos helyzetű területek felzárkóztatásáért - Salgótarján és a Karancs-Medves-vidék turisztikai potenciálja. Földrajzi Közlemények, Vol. 144, No. 1. pp. 43-64

[48] Nagy, A. Sz. - Szabados, Gy. N. - Szendrák, J. - Harangi-Rákos, M. (2019): A Formula 1 társadalmi hatásainak elemzése. In: Bácsné Bába, É. - Müller, A. (szerk.): „Mozgással az egészségért”. A fizikai aktivitás jelentősége a jövő munkavállalóinak egészségmegőrzésében. Debreceni Egyetem, Debrecen. pp. 149-160.

[49] Nagy, E. - Timár, J. - Nagy, G. - Velkey, G. (2015): A társadalmi-térbeli marginalizáció folyamatai a leszakadó vidéki térségekben. Tér és Társadalom, Vol. 29, No. 1. pp. 35-52.

[50] Novák, N. - Kőmíves, P. M. - Harangi-Rákos, M. - Pető, K. (2020): The role of rural areas in the preservation of health. International Review of Applied Sciences and Engineering, Vol. 11, No. 2. pp. 157-166.

[51] Pfau, C. (2016): Hallgatói szabadidősport szervezése és jellemzői a felsőoktatásban. Taylor: Gazdálkodás- és Szervezéstudományi Folyóirat, Vol. 8, No. 4. pp. 5-16.

[52] Pfau, C. - Bács, Z. - Fenyves, V. - Bácsné Bába, E. (2018): Szabadidősport szolgáltatások értékelési lehetőségei Felsőoktatási környezetbe adaptálva. International Journal of Engineering and Management Sciences, Vol. 3, No. 4. pp. 150-164.

[53] Pfau, C. - Kanyó, K. Zs. (2020): A mentális egészség és a szabadidősport kapcsolata. Különleges Bánásmód, Vol. 6, No. 4. pp. 29-40.

[54] Pusztai, B. (2007): „Bajászlé”. Identitás, kanonizáció és márkázás a bajai népünnepélyen. In: Pusztai, B. - Neill, M. (szerk.): Turizmus, fesztiválok és helyi identitás. Halászléfőzés Baján - Tourism, festivals and local identity. Fish soup cooking in Baja, Hungary. University of Edinburg, Edinburgh - Szeged. pp. 7-25. 
Economica XII. Új évf., 1-2. sz. (2021)

ISSN 2560-2322

[55] Ray, C. (1998): Culture, intellectual property and territorial rural development. Sociologia Ruralis, Vol. 38, No. 1. pp. 3-20.

[56] Sampson, L. - Ettman, C. K. - Galea, S. (2020): Urbanization, urbanicity, and depression: a review of the recent global literature. Current Opinion in Psychiatry, Vol. 33, No. 3. pp. 233-244.

[57] Short, B. (2006): Idyllic ruralities. In: Cloke, P. - Mardsen, T. - Mooney, P. (szerk.): Handbook of rural studies. SAGE Publications, London.

[58] Szabó, G. - Harangi-Rákos, M. (2011): A mezőgazdasági szervezetek gazdálkodásának vizsgálata a 2002-2009 közötti időszakban. Gazdálkodás, Vol. 55, No. 4. pp. 358-366.

[59] Szabó, G. - Harangi-Rákos, M. (2020): A koronavírus hatása a mezőgazdaságra, különös tekintettel a foglalkoztatásra. Economica (Szolnok), Vol. 11, No. 3-4. p. 1.

[6o] Szelényi, I. (1973): Városszociológia. Közgazdasági és Jogi Kiadó, Budapest.

[61] Szörényiné Kukorelli, I. (2015): Vidéki térségeink innovációt befogadó képessége - Egy kutatás tapasztalatai. Tér és Társadalom, Vol. 29, No. 1. pp. 97-115.

[62] Vaishar, A. - Štastná, M. (2019): Development of the Czech countryside after 1990: Causes and consequences. In: Bański, J. (szerk.): Three decades of transformation in the East-Central-European Countryside. Springer, Cham. pp. 99-118.

[63] Vasárus, G. (2016): Külterületi szuburbanizáció és szegregáció. Településföldrajzi Tanulmányok, 1. pp. 84-94. 